\title{
The Allocation of Committee Chairs and the Oversight of Coalition Cabinets in Belgium
}

\author{
Mihail Chiru ${ }^{1 *}$ and Lieven De Winter ${ }^{2}$ \\ ${ }^{1}$ Oxford School of Global and Area Studies, University of Oxford, Oxford, UK, and \\ 2Université Catholique de Louvain, Louvain-la-Neuve, Belgium
}

Corresponding author. Email address: mihail.chiru@area.ox.ac.uk

\begin{abstract}
The appointment of committee chairs to monitor the actions of ministers belonging to coalition partners has received considerably less attention than other mechanisms of policing the coalition bargain at executive or legislative level. We take a longitudinal perspective focusing on 11 Belgian cabinets (19802018) to study the determinants of such appointments and whether there is a substitution effect between shadow chairs, junior ministers and coalition agreements. Our findings indicate that the probability of appointing a shadow committee chair is higher when the ideological distance between the minister's party and the coalition is larger. Other key findings are that ministers facing hostile junior ministers tend to be shadowed by committee chairs as well, while shadow chairs are also more frequent in minimum winning coalitions.
\end{abstract}

Keywords: coalition governance; oversight; committee chairs; Belgium

\section{Introduction}

Coalition cabinets are the norm in European politics, and this reality is unlikely to change given the increased fragmentation of party systems and decline of the mainstream parties. The successful functioning of coalition cabinets is dependent on the extent to which coalition partners manage to stick to the agreed common coalition positions, instead of reverting to their own preferences. Inevitably, multiparty cabinets need to delegate collectively policy making power to ministers of individual parties. As any delegation act, this creates the risk that the agent (i.e. the minister) would follow the agenda of her party or her own personal preferences and not the policies of the coalition. The academic literature has documented several oversight mechanisms that can be used by coalition partners to keep tabs on each other's ministers and avoid policy drift. These can be found at executive level (inner cabinets, cabinet committee(s), junior ministers), in the parliamentary arena (legislative review in committees, shadow committee chairs, and coordination between majority parliamentary leaders) or in the extra-parliamentary 
arena (coalition agreements, coalition committees and party summits) (Strøm et al 2010: 522).

A shadow committee chair describes a situation in which the parliamentary committee dealing with the policy jurisdiction of a certain department is headed by an MP from a different coalition party than that of the minister and that MP uses her position to monitor whether the legislation initiated by the minister or other actions of the minister follow the agreed coalition preferences. When ministerial drift is discovered the chair can attempt to correct it or raise the issue to the coalition leaders. The paper draws on an original dataset, covering 11 cabinets and a 39-year period (1980-2018), to investigate the conditions under which committee chair allocation is used in Belgium by coalition parties to keep tabs on ministers of their cabinet partners. We analyze the extent to which the appointment of shadow committee chairs is driven by ideological distance and saliency of the portfolio and whether there is a substitution effect between this practice and the usage of watchdog junior ministers and coalition agreements.

Our paper builds on an expanding literature that analyzes the allocation of committee chairs between parties and provides evidence for the theory that chairs are used strategically for shadowing purposes (Kim and Loewenberg 2005; Clark and Jurgelevičiūtè 2008; Carroll and Cox, 2012; Kraus et al 2020). One alternative explanation is that the chair allocation process is used as compensation mechanism for coalition parties receiving fewer ministerial portfolios than they would be entitled to proportionally (Pukelis 2016). However, the explanatory potential of this explanation is bound to be limited given the fact that most cabinets do not deviate substantially from Gamson's Law in the distribution of portfolios (Falcó-Gimeno and Indridason 2013). Another model of chair allocation implies that the party which controls the relevant ministry would also receive the committee chair position to ensure it has full policy responsibility in that area. Hansen (2018) finds support for this model in the case of Denmark and links it with the main structural feature of Danish cabinets: their minority status, and their need to have some control over the committees in the absence of a supporting majority.

The introduction is followed by a discussion of the theoretical arguments and empirical evidence which inspired this study and a presentation of the main hypotheses that will be tested. We then introduce the rationales for our case selection and the official rules that govern committee chair allocation and the chairs' formal power in the Belgian legislature. Next, we present the details of the research design: the data sources, variables' operationalization and methods. The fifth section discusses the results of the multivariate analyses followed by several robustness checks. The conclusions discuss the implications of the main findings and point to further directions of research.

\section{Committee chair shadowing: previous evidence and new hypotheses}


In most parliaments, committee chairs have influence over the committee agenda, are part of the legislature's coordinating bodies, receive substantial media attention (Gattermann and Vasilopoulou 2015; Rosenthal 2018; Chiru and Gherghina 2019; Fernandes et al 2019; Chiru 2020) and are thought to play a key role in attempts of correcting ministerial drift (Fortunato et al 2017; Carroll and Cox 2012). Nevertheless, some recent work has cast doubt over the shadowing argument regarding committee chairs. For instance, some authors argue there is not more scrutiny of cabinet legislation when the committee is chaired by a coalition partner MP, i.e. shadow chair, compared to when the chair is an MP representing the minister's party (Fortunato et al 2017; Fortunato 2018). Instead, higher levels of scrutiny are registered when the committee is chaired by an opposition MP. However, evidence that coalition parties do use committee chairs to control their partners and shape legislation emerged from an analysis of German state parliaments (Kraus et al 2020). Their findings suggest that it is more likely that a legislative proposal is changed at the committee stage if the committee chair belongs to the coalition partner.

In most Western European Parliaments committee chairs have rather limited formal prerogatives, so their capacity to influence committee work in general is probably not very high (Sieberer and Höhmann 2017). ${ }^{1}$ The same study found that there does not seem to be a correlation between committee chair formal powers and the incidence of shadow committee chairs. Nevertheless, the existence of formal power for chairs within committee business is not a necessary condition for monitoring the activity of the minister. The literature cited also does not necessarily rely on such assumptions about formal powers, but rather consider the committee chair to simply be the most elevated post within the parliament dedicated to the jurisdiction's policy. In the next paragraphs we present the arguments behind our four hypotheses, which focus on the ways in which ideological distance, portfolio salience and alternative mechanisms of monitoring the behavior of ministers and implementing the coalition's agreed policies shape the likelihood of committee chair shadowing.

First, the risk of ministerial drift is substantially higher when the coalition partners have very different ideological positions and policy preferences. It is therefore reasonable to expect considerably larger monitoring efforts in such situations and previous studies have confirmed this to be the case with respect not only to watchdog junior ministers (Lipsmeyer and Pierce 2011), but also for committee chairs. Kim and Loewenberg (2005) in a longitudinal study of German cabinets and Carroll and Cox (2012) in a comparative study of 19 democracies have shown that the ideological distance between a minister's party and the other coalition parties increases the likelihood of shadowing by committee

\footnotetext{
${ }^{1}$ For the formal powers and informal influence of committee chairs in Belgium, see El Berhoumi and
} Pitseys (2016). 
chairs. Instead, a study of intra-coalition politics in the Baltic States found that ideological distance affects the likelihood that committee chairs shadow ministers only indirectly. Thus, cabinet parties which are ideologically more distant than the other parties tend to receive fewer committee chair positions overall, which constrains their oversight capacities (Pukelis 2018: 58-61). Because the assessment of ideological distance by coalition parties could happen either at party or at portfolio level, we formulate two hypotheses:

H.1a: The larger the ideological distance between the minister's party and the cabinet average position on the left-right scale the more likely she is to be shadowed by the committee chair.

$\mathrm{H} .1 \mathrm{~b}$ : The larger the ideological distance between the minister's party and the cabinet average position on the policy areas in the jurisdiction of the department, the more likely she is to be shadowed by the committee chair.

Second, policy salience influences not only which departments parties pursue as coalition payoffs (Bäck et al 2011; Raabe and Linhart 2015; Ecker et al. 2015) but also which committee chair positions they seek to obtain (Evans 2020). Previous research has also shown that there is a higher likelihood of shadowing by junior ministers when the department deals with a more salient policy area (Lipsmeyer and Pierce 2011). Although not tested directly previously, it would be reasonable to expect committee chairs to shadow ministers that are more salient for the coalition as a whole, as agency drift in such cases involves substantive political costs because it hurts important policy interests of the parties or has high electoral costs attached. Conversely, coalition partners have few incentives to monitor each other if the policy area in question is politically irrelevant for them.

H.2: The higher the saliency assigned by the cabinet parties to the policy areas in the jurisdiction of the department, the more likely it is that the minister will be shadowed by the committee chair.

Third, previous scholarship on intra-coalition politics has illustrated convincingly the frequent usage of watchdog junior ministers as a key policing mechanism of coalition bargains (Thies 2001; De Winter et al 2003; Lipsmeyer and Pierce 2011; Martin and Vanberg 2011; Greene and Jensen 2016). However, the literature is much more ambivalent with respect to the relationship between appointing junior ministers and committee chairs for shadowing purposes. Thus, while some evidence would indicate a substitution effect, other studies found that the two practices are used simultaneously. Drawing on the German case, two studies (Thies 2001; Kim and Loewenberg 2005) have hypothesized that watchdog junior ministers and committee chairs are used alternatively as mechanisms of keeping tabs on the ministers of coalition partners. Analyzing data from the German Bundestag and federal cabinets covering a 32-year period (1966-1998), Kim and Loewenberg (2005) concluded that the higher the share of ministers shadowed by their junior ministers, the less frequent the appointment of shadow committee chairs. 
Somewhat related, Martin and Vanberg (2011) found a substitution effect between using junior ministers for information gathering and the level of scrutiny by parliamentary committees in systems with strong parliamentary institutions.

However, other studies have revealed a positive association between the two practices: in young democracies, such as Lithuania and Latvia, when ministries are shadowed, they are shadowed by both junior ministers and committee chairs (Clark and Jurgelevičiūtè, 2008: 637; Pukelis 2018: 74). While using both types of shadowing mechanisms might be costly in terms of negotiating such positions and the efforts required for monitoring, their deployment in tandem is likely to be more efficient. ${ }^{2}$ As speculated by Carroll and Cox (2012: 223): 'junior ministers may leak information to committee chairs, who can then slow down bills that have already reached the assembly, giving coalition partners time to negotiate their differences'. Such efficiency gains might therefore outweigh the opportunity costs induced by the simultaneous usage of multiple oversight mechanisms. ${ }^{3}$ H.3: Ministers facing hostile junior ministers will also be shadowed by committee chairs.

Fourth, and in a similar manner, we expect cabinets that have detailed coalitions agreements to be keener to appoint shadowing committee chairs to make sure that these are implemented (Kim and Loewenberg 2005: 1108). The need for a long agreement may be due to ideological distance or reduced mutual trust, and as such it should call for as many oversight mechanisms as possible. Research on coalition agreements has shown that on average, in Western Europe, $90 \%$ of their content is policy related, the rest being taken up by procedural rules and office distribution (Strøm et al 2010: 530). Having thorough policy deals agreed explicitly by the coalition in a contract would make monitoring easier (Bowler et al 2016: 1275), implying that committee chairs would be better equipped to detect ministerial drift and to understand which amendments arising on the committee stage would go against the coalition's preferred position. In line with this complementarity argument, previous research has found that coalition agreements tend to be longer when junior ministers are appointed to keep tabs on ministers from different parties (Indridason \& Kristinsson 2013).

One counterargument to the multiple monitoring arrangement could be that governing parties which have put together long coalition agreements have already resolved their differences and therefore do not need to waste resources monitoring the behavior of their partners. Nevertheless, such a scenario would imply a high level of mutual trust, which is a rather scarce resource, especially for parties that have not governed together before.

\footnotetext{
${ }^{2}$ In coalitions of three or more parties, the simultaneous use of shadowing chairs and junior ministers allows for "triangular" control over a minister of another party.

${ }^{3}$ In the Belgian case there is a risk of endogeneity for this relationship, i.e., the appointment of the junior minister to be influenced by that of the committee chair, for those cabinets that took a very long time to form.
} 
H.4: The more detailed the coalition agreement the more likely it is that ministers will be shadowed by committee chairs.

Beyond the four hypotheses we control for the cabinet type, the minister's party seat share, and the number of seats held by chair's party. The survival of minimum winning coalitions is much more dependent on the level of policy and office gains obtained by each of the coalition parties through their government participation than a surplus majority cabinet which, by definition, can even afford to see one of the partners depart (Damgaard 2008; Chiru 2015). For this reason, we would expect minimum winning coalitions to be much more careful in monitoring the coalition bargain and therefore to use more frequently shadow chairs than surplus majority cabinets. Conversely, oversized coalitions usually include more parties than minimum winning coalitions, which increases the opportunities for shadowing. .

Cabinet parties which control a large number of seats would have a smaller probability of being shadowed given the proportionality of committee chair allocation. On the contrary, large parties would have a higher chance of shadowing smaller cabinet parties when they are the one appointing the committee chair - an intuition which should be captured by the number of seats held by chair's party. Large parties have an advantage in Belgium not only because of the proportionality of the chair allocation process, but also because the size affects the order in which committee chairs are picked, as described below.

\section{Case selection and the rules regarding committee chair selection and powers}

\subsection{Case Selection}

Belgium is an interesting but complex case for coalition research. Nearly all the 43 postwar governments were coalition cabinets. In the period under analysis (1980-2018), due to soaring party fragmentation (ENP between 6.8 to 9.1), cabinets contained four to six parties. Two cabinets were unconnected (Verhofstadt I \& II, 1999-2007). About half of the coalitions were Minimal Winning, the other were surplus coalitions. Some had narrow majorities, other could count on large majorities. Coalition formation duration varies from 15 days to a world record of 541 days. The left-right polarization index ${ }^{4}$ varies from only 1.5 for the compact coalition of Martens V to 5.2 for the heterogeneous cabinet of Verhofstadt I. Finally, given the complexity of cabinet formation and maintenance, a comparatively large number of mechanisms have been installed to contain or solve interparty cabinet conflicts (De Winter, Timmermans \& Dumont, 2003).

\footnotetext{
${ }^{4}$ Computed based on the CHES data as the difference between the left-right position of the most rightwing party in the cabinet and that of the most left-wing government party.
} 
Hence, the longitudinal analysis of nearly 40 years of coalition politics can help us to unveil factors that can explain the variation in the use of shadow committee chairs in Belgian coalition governance.

\subsection{Formal rules regarding the allocation of committee chairs and their powers}

In the Chamber of Representatives, the nomination of committee chairs follows several formal and informal rules. Chairs are allotted to parliamentary party groups in a proportional way (Règlement de la Chambre des représentants 2019, art 158), following the D'Hondt method. ${ }^{5}$ In order to be recognized and subsidized as a group, a party needs at least 5 MPs (Règlement... 2019; art 11.2). Both rules lead to an overrepresentation of large parties among committee chairs. After each election, the Conference of the Group leaders defines the number of parliamentary positions allotted to each group. The parties choose the committees they want to chair in the order of their size: thus, the largest party has the first choice, followed by the second party, and so on. Ideally one would incorporate in the empirical modeling strategy the fact that the choice of committees happens in such a sequence, but unfortunately, we lack this detailed information.

In one of the first plenary meetings ( $3^{\text {rd }}$ in 2019), the Speaker announces, upon proposal of the Conference of the Group Leaders, the MPs who will chair the permanent committees, while each committee nominates a first and second vice-chair during its first meeting. ${ }^{6}$

According to a comparative analysis of information acquisition, rewrite authority and timetable control in 31 democracies, Belgian parliamentary committees stand among the strongest in Western Europe (André et al 2016: 111) which bodes well for their usage in the legislative review of ministerial proposals. Nevertheless, and as other have observed, the formal powers attributed exclusively to committee chairs in Belgium are at best moderate (Sieberer and Höhmann 2017). The chair shares committee agenda with the majority of the committee members and the Speaker (Règlement... 2019, art 24). On the committee agenda, government bills (including budget bills) have priority over private member bills. But a simple majority of committee members could overrule a chair's agenda. Thus, agenda setting is rather consensual between majority and minority committee members, and the committee as a whole vis-à-vis the minister. The chair decides on scheduling a meeting of the committee, delaying or suspending it. The chairs' influence is also derived from participation in the legislature's coordinating bodies, as

\footnotetext{
${ }^{5}$ In older standing orders, from 1995 and 2003 the proportionality principle was not mentioned. Instead, it was mentioned that leaders of the large PPGs who are members of the House Bureau (the chamber's leadership) have the right to chair the permanent committees in which they sit.

${ }^{6}$ The chair of a 'temporary' or 'special' committee are nominated by its members (Règlement... 2019, art. 20). A variety of rules apply to in-house committees: petitions, naturalisations, comptabilité, prosecutions, control party finance, defense expenditures, etc).
} 
often chairs are members of the House Bureau and of the Conference of Presidents which decides on the work schedule of the House (Règlement... 2019, art 14; art. 19).

Figure 1 below shows that there is substantial variation in the allocation of committee chairs both between cabinets and across committees. Thus, the proportion of committee chairs shadowing ministers varies between $18.2 \%$ (Leterme I) and 60\% (Dehaene I and II). The different number of committees is due either to the changes in the structure of the committees (e.g. the disappearance of the business committee) or because certain committees did not have a corresponding department in certain cabinets (e.g. the committee for institutional reform).

Figure 1: The allocation of committee chairs by government and committee

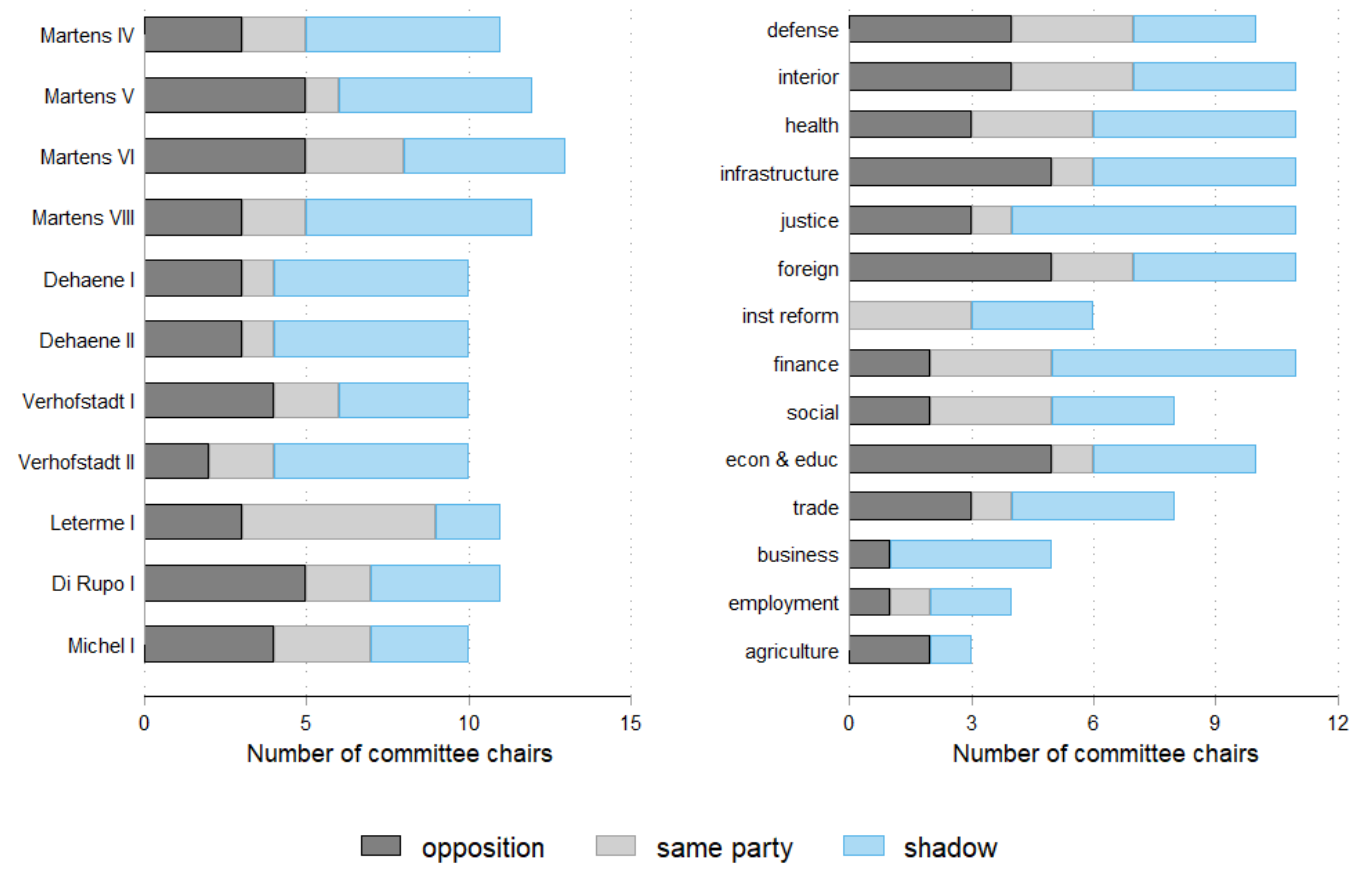

\section{Data, operationalization of variables and methods}

We collected ourselves the data regarding committee chairs' party affiliation in the 1980s, early 1990s and for the most recent cabinet included in the sample. We draw on Van Hauwaert and Janssen (2017) for the 1995-2014 data.

The first step of the analysis was to match the permanent committees and the ministries based on their policy jurisdiction. The full matching of the committees and portfolios for the 11 governments is displayed in table A1 in the Appendix. The dependent variable is coded 1 if the committee that shares the same or a very similar policy jurisdiction as the department is chaired by a politician from a different coalition partner than the minister and 0 if the committee is chaired by an MP from the same party or from the opposition. 
The ideological distance - party level variable indicates the absolute difference between the minister's party left-right position and the seat-weighted average position of the cabinet. This was computed using the parties' left right scores retrieved from the Chapel Hill Expert Surveys (Ray 1999; Steenbergen and Marks 2007; Hooghe et al 2010; Bakker et al 2015, Polk et al 2017).

The ideological distance - portfolio level variable indicates the natural logarithm of the absolute difference between the minister's party positions on the policy dimensions that pertain to the jurisdiction of the department and the seat-weighted average position of the cabinet on the same dimensions, using the MARPOR (Volkens et al 2020) manifesto data.

Portfolio saliency indicates the seat-weighted sum of the cabinet parties' assigned salience to the policy areas included in the jurisdiction of the department, using again MARPOR data. Our matching of MARPOR categories to policy areas follows past similar analyses (Bäck et al 2011; Hohendorf et al 2020) and is presented in detail in Table A2 in the Appendix.

Watchdog junior minister is a dichotomous variable coded 1 if a junior minister assigned to the department under consideration in that cabinet belongs to another coalition party than the minister. The data regarding this variable and the length of the coalition agreement was retrieved from De Winter and Dumont (2021).

Table 1: Descriptive statistics

\begin{tabular}{llllll}
\hline & Mean & S.D. & Min. & Max. & N. \\
\hline Shadow chair & 0.45 & 0.50 & 0.00 & 1.00 & 120 \\
Ideological distance - party level & 1.17 & 0.59 & 0.03 & 2.51 & 120 \\
Ideological distance - portfolio level & 0.96 & 1.38 & -4.61 & 3.10 & 120 \\
Portfolio saliency & 12.37 & 10.43 & 0.00 & 40.60 & 120 \\
Watchdog junior minister & 0.11 & 0.31 & 0.00 & 1.00 & 120 \\
Coalition agreement length & 24281.67 & 17347.74 & 6950 & 57100 & 120 \\
Minimum winning coalition & 0.54 & 0.50 & 0.00 & 1.00 & 120 \\
Minister party's seat \% & 14.76 & 4.67 & 6.00 & 26.89 & 120 \\
N seats held by chair's party & 25.50 & 10.29 & 6.00 & 57.00 & 120 \\
\hline
\end{tabular}

The information regarding the cabinet type (minimal winning coalition vs. surplus majority coalition), the number of seats held by the committee chair party and minister party were retrieved from PARLGOV (Döring and Manow 2019). Table 1 above presents the descriptive statistics for the variables in our sample. While $45 \%$ of the committee chairminister combinations satisfy the shadowing condition, only $11 \%$ of the departments 
feature a junior minister. ${ }^{7}$ As the dependent variable is dichotomous, we use a binary logistic regression for estimation. Moreover, because the decision of a coalition party to monitor the ministers of its partners might trigger similar behavior from the latter actors ${ }^{8}$ we use robust standard errors clustered by cabinet.

\section{What drives the usage of committee chairs for shadowing in Belgium?}

Table 2 below reports the results of two logistic regressions. While the first regression draws on the full sample, the second one includes only the committees chaired by MPs who are members of cabinet parties. ${ }^{9}$ Virtually all independent variables and controls behave similarly in both models. Irrespective of model specification hypothesis $1 \mathrm{a}$ is corroborated: the higher the left-right distance between the party of the minister and the mean cabinet position, the higher the likelihood of having a committee chair from a different coalition partner. The magnitude of this effect is illustrated in Figure 2 below. Against our expectations, ideological distance at the level of the portfolio and the saliency of the portfolio do not seem to influence the allocation of committee chairs in neither of the models. Future studies could attempt to test whether the former non-finding is due to relying on manifesto data designed first and foremost to capture the saliency of policy issues for parties and not their positions (Laver 2001).

Hypothesis 3 is corroborated as there is no substitution effect for watchdog junior ministers. On the contrary, ministers that face 'hostile' juniors are very often also confronted with shadow committee chairs. Ministers serving in minimum winning coalition cabinets have a higher likelihood to be shadowed by committee chairs than ministers who are part of surplus majority cabinets. The magnitudes of these effects are illustrated in Figure 3 below.

\footnotetext{
${ }^{7}$ Of the 13 cases in which a watchdog junior minister was appointed, only in 3 did she share the same party affiliation as the committee chair.

${ }^{8}$ This would imply the assumption of independence of observations would not hold for cases originating in the same cabinet.

${ }^{9}$ We also report the results of the regression ran on the full sample because all committee chair positions are up for grabs. Thus, even those that end up with opposition chairs could have been picked by cabinet parties.
} 
Table 2: Determinants of chair shadowing ministers (logistic regression)

\begin{tabular}{lll}
\hline & M1 & M2 \\
\hline Ideological distance - party level & $2.44^{* * *}$ & $2.16^{*}$ \\
& $(0.84)$ & $(0.87)$ \\
Ideological distance - portfolio level & 1.05 & 1.01 \\
& $(0.26)$ & $(0.29)$ \\
Portfolio saliency & 0.99 & 0.98 \\
& $(0.02)$ & $(0.03)$ \\
Watchdog junior minister & $2.52^{*}$ & 5.30 \\
& $(1.24)$ & $(6.57)$ \\
Coalition agreement length & 1.00 & 1.00 \\
& $(0.00)$ & $(0.00)$ \\
Minimum winning coalition & $1.95^{* * *}$ & $2.49^{* *}$ \\
& $(0.42)$ & $(1.05)$ \\
Minister party's seat \% & 1.02 & 0.97 \\
& $(0.04)$ & $(0.03)$ \\
Number seats held by chair's party & $1.04^{* * *}$ & 1.00 \\
& $(0.02)$ & $(0.02)$ \\
\hline N & 120 & 79 \\
McFadden's ${ }^{2}$ & 0.078 & 0.084 \\
\hline
\end{tabular}

Notes: Significance at ${ }^{*} \mathrm{p}<0.10,{ }^{* *} \mathrm{p}<0.05,{ }^{* * *} \mathrm{p}<0.01$

Cell entries are odds ratios. Robust standard errors clustered by cabinet in parentheses.

We find no evidence for hypothesis 4 . Thus, ministers from cabinets that were negotiated for a long time and are based on more detailed coalition agreements have the same chance of being shadowed as their counterparts from cabinets with shorter coalition agreements. A possible explanation has to do with the fact that in Belgium coalition agreements are taken very seriously, irrespective of their length (Moury 2009; Timmermmans \& Moury 2006). A minister can only send a bill to the House and the relevant committee when it has the approval of the full council of ministers. Hence, verification of ministers' bills conformity to the coalition agreement is exercised at executive level, and any controversial matter will already be streamlined by the inner cabinet ('Kerncabinet', including the PM and all vice-PMs) (De Winter \& Dumont 2006).

Based on model 1 in Table 2, Figure 2 below plots the predicted probability of committee chair shadowing depending on the level of ideological distance between the minister's party and the cabinet mean left right position, weighted by the seat contribution of each party to the coalition. The Figure indicates that when the position of the minister's party is virtually identical to that of the cabinet, the likelihood of shadowing is $24 \%$, whereas at the maximum distance observed in the sample (2.5), the probability that the committee chair is allocated to another coalition partner is $70 \%$, all other things being equal. 
Figure 2: Ideological distance (party level) and likelihood of minister being shadowed

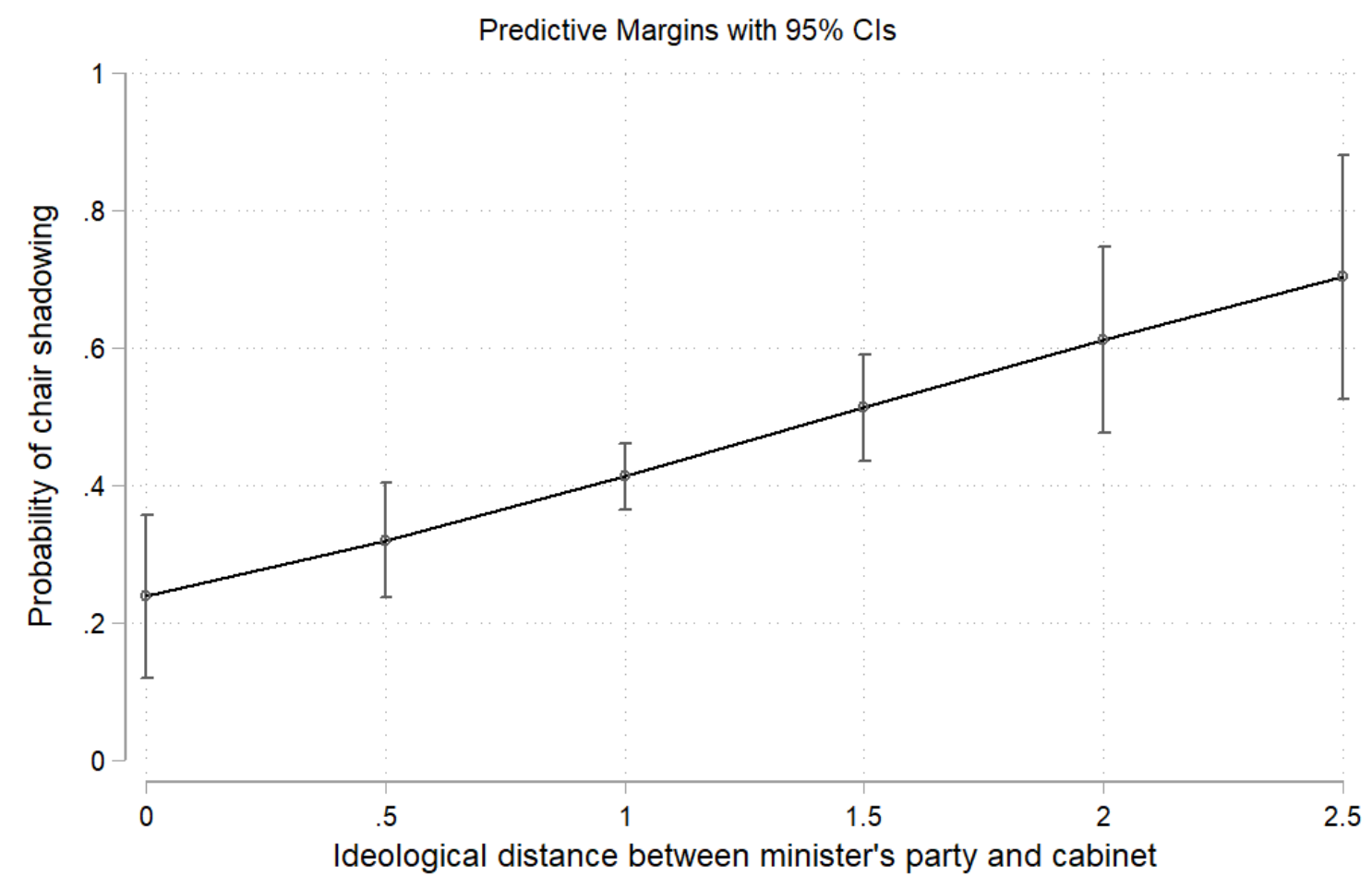

Drawing on the same model 1 in Table 2, Figure 3 plots predicted probabilities for two other independent variables. The left side panel of Figure 3 illustrates that, indeed, watchdog junior ministers have a positive impact on the likelihood of shadowing, and the effect is relatively large. Thus, departments which include junior ministers from coalition partners are much more likely to also be shadowed by committee chairs than ministers who work with juniors from their own party, or who lack deputies. In the former case the probability of shadowing is almost $21 \%$ higher than in the latter case.

The right-side panel of Figure 3 indicates that ministers of surplus majority cabinets have a $37 \%$ chance of being shadowed by committee chairs, whereas for minimum winning coalition ministers the probability amounts to $52 \%$. 
Figure 3: Watchdog junior ministers, cabinet type and likelihood of minister being shadowed
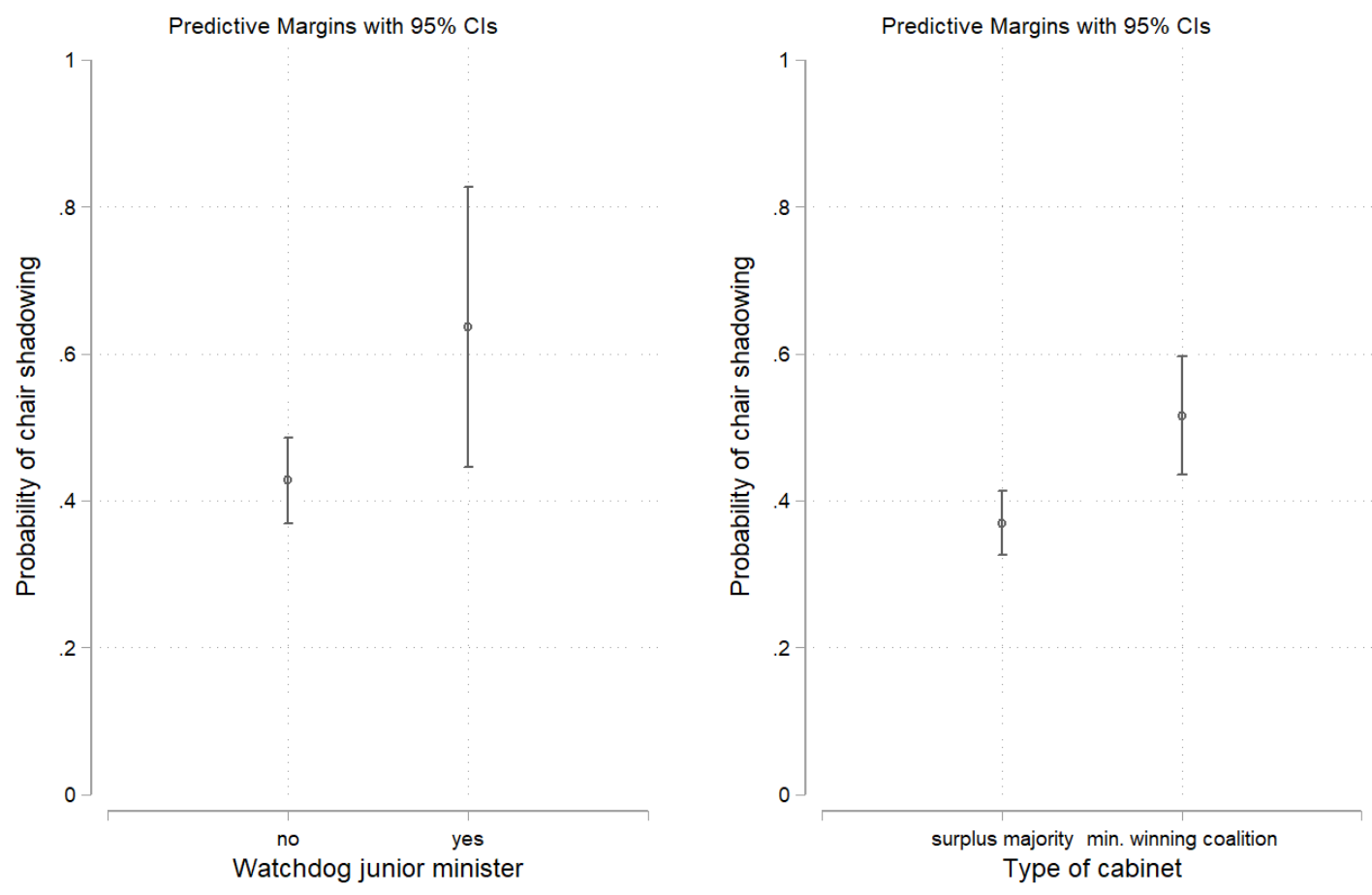

\subsection{Robustness checks}

The first robustness check was to re-run the model with a multinomial logistic regression having as DV a variable with three categories: chair allocated to opposition party, chair allocated to the party of the minister and shadowing chair. The results of this regressions (having as reference category the opposition committee chairs) are reported in table A3 in the appendix. Hypothesis 1a is again corroborated: higher ideological distance between the minister's party and the cabinet leads to a higher likelihood of appointing a shadow chair than one from the ranks of the opposition parties. Watchdog junior ministers seem also to have a positive effect on appointing a shadow chair, but the variable does not reach conventional levels of statistical significance.

The length of cabinet formation can be considered another proxy for the level of disagreement between the coalition parties and the need to police the coalition bargain. In the Belgian case, this formation duration is strongly correlated with the length of the coalition agreement, thus we ran an alternative model in which the latter variable was replaced by the former. As it can been seen from Table A4, this variable did not make a difference and the main results remained virtually identical, both in terms of direction and magnitude of effects.

Another robustness check was to replace the average portfolio saliency measure with a variable indicating the portfolio saliency only for the coalition party that actually 
nominated the committee chair. The results are reported in Model in Table A5 in the Appendix, and they show this alternative operationalization does not make a difference. Moreover, we also replaced the departmental salience variable with a continuous variable based on the assessment of the Belgian case in the Druckman and Warwick (2005) expert survey on portfolio salience. As shown by Models 2 and 3 in the same Table, the main results are robust to this change.

Last but not least, for six of the legislatures (1988-2010) we analyzed whether there is complementarity between the usage of shadow committee chairs and monitoring via parliamentary questions. This was motivated by the findings of recent research which has shown that coalition parties in UK (Martin and Whitaker 2019) and Germany (Höhmann and Sieberer 2020) also use parliamentary questions to keep tabs on their partners' ministers. Drawing on data from the Belgian Comparative Agendas Project (Walgrave et al 2019) we computed the shares of oral questions and interpellations ${ }^{10}$ addressed to each department by MPs belonging to the other coalition parties than the party appointing the respective minister. We found no association between this variable and the usage of shadow committee chairs.

\section{Conclusions}

This paper contributes to the expanding literature on oversight mechanisms used by cabinet coalition partners to avoid ministerial drift by re-testing in a more fine-grained manner previous findings about the roles of ideologically distance and portfolio saliency in the use of committee chairs for shadowing purposes and by revealing the relation between this practice and other monitoring arrangements. Thus, our analysis of this unexplored field of Belgian coalition governance indicates that shadowing ministers by allocating committee chairs to other coalition parties is present but varies both between cabinets (from $18 \%$ to $60 \%$ ) and across committees.

Our results reveal that ideological distance matters at party but not at portfolio level: the higher the left-right distance between the party of the minister and the mean cabinet position the higher the likelihood of having a committee chair from a different coalition partner.

On the contrary, ideological distance at the level of the portfolio does not seem to influence committee chair shadowing. This might be because for such a measure to work it would imply a very demanding level of detailed knowledge on each party's respective policy preferences from the coalition leaders. Alternatively, the non-finding might be due to the measurement of this variable: manifesto data designed mainly to capture the saliency of policy issues for parties and not their positions. Future studies relying on

\footnotetext{
${ }^{10}$ In the Belgian context, these are more visible and have a much higher control potential compared to written parliamentary questions.
} 
different data to measure ideological distance at the level of portfolio and portfolio salience could also consider the interaction effect between the two variables as theoretically, incentives to monitor each other are at a maximum if the coalition parties are ideologically far apart in a salient policy area.

Surprisingly, the saliency of the department to the cabinet parties does not affect the probability of committee chair shadowing, irrespective of the operationalization: mean weighted saliency for the coalition parties, saliency for the party that actually nominated the committee chair, or as perceived by experts.

We find no substitution effect for watchdog junior ministers, as ministers that face 'hostile' juniors are very often also confronted with shadow committee chairs. Ministers serving in minimum winning coalition cabinets have a higher likelihood to be shadowed by committee chairs than ministers who are part of surplus majority cabinets. On the other hand, we could not corroborate the hypothesis that ministers from cabinets that are based on more detailed coalition agreements have a higher chance of being shadowed than their counterparts from cabinets with shorter coalition agreements. The results of these multivariate analyses were confirmed by a number of robustness checks.

Further research could explore the institutional and partisan conditions under which coalition partners decide to use in tandem watchdog junior ministers and shadow committee chairs to avoid ministerial drift. A reasonable expectation would be that this would not happen in systems with weak parliamentary committees (Martin and Vanberg 2011). Another hypothesis worth exploring is whether the allocation of committee chairs is also used as a compensation mechanism for the coalition parties' anticipated future electoral losses. A survey experiment of Irish legislators illustrated that political elites are willing to compensate a party that is likely to be penalized by voters for its cabinet participation by allotting it more cabinet seats (Martin 2018). 


\section{References}

André, A., Depauw, S., \& Martin, S. (2016). “Trust Is Good, Control Is Better" Multiparty Government and Legislative Organization. Political Research Quarterly, 69(1), 108-120.

Bäck, H., Debus, M. and Dumont, P., 2011. Who gets what in coalition governments? Predictors of portfolio allocation in parliamentary democracies. European Journal of Political Research, 50(4), pp.441-478.

Bakker, R., de Vries, C., Edwards, E., Hooghe, L., Jolly, S., Marks, G., Polk, J., Rovny, J., Steenbergen, M., Vachudova, M., 2015. 'Measuring Party Positions in Europe: The Chapel Hill Expert Survey Trend File, 1999-2010', Party Politics, 21(1): 143152.

Bowler, S., Indridason, I. H., Bräuninger, T., \& Debus, M. (2016). Let's Just agree to disagree: dispute resolution mechanisms in coalition agreements. The Journal of Politics, 78(4), 1264-1278.

Carroll, R., \& Cox, G. W. (2012). Shadowing ministers: Monitoring partners in coalition governments. Comparative Political Studies, 45(2), 220-236.

Chiru, M. (2015). Early marriages last longer: Pre-electoral coalitions and government survival in Europe. Government and Opposition, 50(2), 165-188.

Chiru, M., and Gherghina, S. (2019). Committee chair selection under high informational and organizational constraints, Party Politics, 25(4), 547-558.

Chiru, M. (2020). Loyal soldiers or seasoned leaders? The selection of committee chairs in the European Parliament. Journal of European Public Policy, 27(4): 612-629.

Clark, T. D., \& Jurgelevičiūtè, D. (2008). "“Keeping Tabs" on Coalition Partners': a Theoretically Salient Case Study of Lithuanian Coalitional Governments. EuropeAsia Studies, 60(4): 631-642.

Damgaard, E. (2008), 'Cabinet Termination', in K. Strøm, W.C. Müller and T. Bergman (eds.), Cabinets and Coalition Bargaining: The Democratic Life Cycle in Western Europe (Oxford: Oxford University Press): 301-26

De Winter, L., Timmermans, A. \& Dumont, P. (2003). “Belgium: On Government Agreements, Evangelists, Followers, and Heretics." In Müller, W. C. and Strøm, K. (eds.). Coalition Governments in Western Europe. Oxford: Oxford University Press, pp. 300-55.

De Winter, L., \& Dumont, P. (2006). Do Belgian parties undermine the democratic chain of delegation?. West European Politics, 29(5): 957-976.

De Winter, L., \& Dumont, P. 2021., “Belgium” in Bergman, T., Müller, W. C. and Strøm, K. (eds.). Coalition Governance in Western Europe. Oxford: Oxford University Press

Döring, H., \& Manow, P. (2019). 'Parliaments and governments database (ParlGov): Information on parties, elections and cabinets in modern democracies'. Development version. 
Druckman, J. N., \& Warwick, P. V. (2005). The missing piece: Measuring portfolio salience in Western European parliamentary democracies. European Journal of Political Research, 44(1): 17-42.

Ecker, A., Meyer, T. M., \& Müller, W. C. (2015). The distribution of individual cabinet positions in coalition governments: A sequential approach. European journal of political research, 54(4), 802-818.

El Berhoumi, M., \& Pitseys, J. (2016). L'obstruction parlementaire en Belgique, Courrier hebdomadaire du CRISP, $\mathrm{n}^{\circ}$ 2289-2290, 5-78.

Evans, M. (2020). Analysing Payoff Salience in Coalition Allocation: Ministers, Deputy Ministers and Committee Chairs. Government and Opposition, 55(3), 490-510.

Falcó-Gimeno, A., \& Indridason, I. H. (2013). Uncertainty, complexity, and Gamson's Law: Comparing coalition formation in Western Europe. West European Politics, 36(1), 221-247.

Fernandes, J.M., Riera, P., \& Cantú, F. (2019) The politics of committee chairs assignment in Ireland and Spain, Parliamentary Affairs72(1): 182-201

Fortunato, D. (2019). Legislative review and party differentiation in coalition governments. American Political Science Review, 113(1): 242-247.

Fortunato, D., Martin, L. W., \& Vanberg, G. (2017). Committee Chairs and Legislative Review in Parliamentary Democracies. British Journal of Political Science, 1-13.

Gattermann, K., \& Vasilopoulou, S. (2015) Absent yet popular? Explaining news visibility of members of the European Parliament, European Journal of Political Research 54(1): 121-140.

Greene, Z., \& Jensen, C. B. (2016). Manifestos, salience and junior ministerial appointments. Party Politics, 22(3), 382-392.

Hansen, M. E. (2018). Distributing Chairs and Seats in Committees: A Parliamentary Perspective. Parliamentary Affairs, 72(1): 202-222.

Hohendorf, L., Saalfeld, T. and Sieberer, U., (2020). Veto power fosters cooperative behaviour: institutional incentives and government-opposition voting in the German Bundestag. West European Politics, pp.1-25.

Höhmann, D., \& Sieberer, U. (2020). Parliamentary questions as a control mechanism in coalition governments. West European Politics, 43(1), 225-249.

Hooghe, L., Bakker, R., Brigevich, A., De Vries, C., Edwards, E., Marks, G., Rovny, J., Steenbergen, M. \& Vachudova, M. (2010). Reliability and validity of measuring party positions: The Chapel Hill expert surveys of 2002 and 2006. European Journal of Political Research, 49(5): 687-703.

Indridason, I. H., \& Kristinsson, G. H. (2013). Making words count: Coalition agreements and cabinet management. European Journal of Political Research, 52(6), $822-846$. 
Lipsmeyer, C. S., \& Pierce, H. N. (2011). The eyes that bind: Junior ministers as oversight mechanisms in coalition governments. The Journal of Politics, 73(4): 1152-1164.

Krauss, S., Praprotnik. K., \& Thürk, M. (2020): Extra-coalitional policy bargaining: investigating the power of committee chairs, The Journal of Legislative Studies, DOI: $10.1080 / 13572334.2020 .1809214$

Laver, M. (2001). Position and salience in the policies of political actors. In Laver, M. (ed.) Estimating the policy positions of political actors. London/New York: Routledge, pp. 66-75

Martin, S. (2018). Bargaining in legislatures, portfolio allocation, and the electoral costs of governing. West European Politics, 41(5): 1166-1190.

Martin, L. W., \& Vanberg, G. (2011). Parliaments and coalitions: The role of legislative institutions in multiparty governance. OUP Oxford.

Martin, S., \& Whitaker, R. (2019). Beyond committees: parliamentary oversight of coalition government in Britain. West European Politics, 42(7), 1464-1486.

Moury, C. (2009). Coalition government and party mandate: explaining ministerial room of manoeuvre vis-à-vis the coalition agreement. Sociologia, problemas e práticas, (59), 125-156.

Polk, J., Rovny, J., Bakker, R., Edwards, E., Hooghe, L., Jolly, S., Koedam, J., Kostelka, F., Marks, G., Schumacher, G., Steenbergen, M., Vachudova, M., and Zilovic, M. (2017). Explaining the salience of anti-elitism and reducing political corruption for political parties in Europe with the 2014 Chapel Hill Expert Survey data. Research \& Politics, 4(1): 1-9.

Pukelis, L. (2016). The role of parliamentary committee chairs in coalition governments: office and policy theses reconsidered. East European Politics, 32(2), 215-235.

Pukelis, L. (2018). Informal mutual oversight mechanisms in coalition governments: Insights from the Baltic states for theory building. Tartu: University of Tartu Press.

Raabe, J., \& Linhart, E. (2015). Does substance matter? A model of qualitative portfolio allocation and application to German state governments between 1990 and 2010. Party Politics, 21(3), 481-492.

Ray, L. (1999), "Measuring party orientations toward European integration: Results from an expert survey," European Journal of Political Research, 36.2: 283-306.

Rosenthal, M. (2018). Agenda Control by Committee Chairs in Fragmented Multi-party Parliaments: A Knesset Case Study. Israel Studies Review, 33(1), 61-80.

Seki, K., \& Williams, L. K. (2014). “Updating the Party Government Data Set.” Electoral Studies. 34: 270-279.

Sieberer, U., \& Höhmann, D. (2017). Shadow chairs as monitoring device? A comparative analysis of committee chair powers in Western European parliaments. The Journal of Legislative Studies, 23(3): 301-325. 
Steenbergen, M. \& Marks, G. (2007). Evaluating Expert Judgments, European Journal of Political Research, 46(3): 347-366.

Strøm, K., Müller, W. C., \& Smith, D. M. (2010). Parliamentary control of coalition governments. Annual Review of Political Science, 13, 517-535.

Thies, M. F. (2001). Keeping tabs on partners: The logic of delegation in coalition governments. American Journal of Political Science, 45, 580-598.

Timmermans, A., \& Moury, C. (2006). Coalition governance in Belgium and The Netherlands: Rising government stability against all electoral odds. Acta Politica, 41(4), 389-407.

Van Hauwaert, S.M., \& Janssen, C. (2017). Pathways to Power: The Political Representation of Citizens of Immigrant Origin in Belgium (BEPATHWAYS). Cologne: GESIS Data Archive.

Volkens, A., Burst, Tobias, Krause, W., Lehmann, P., Matthieß, T., Merz, N., Regel, S., Weßels, B. \& Zehnter, L. (2020): The Manifesto Data Collection. Manifesto Project (MRG / CMP / MARPOR). Version 2020a. Berlin: Wissenschaftszentrum Berlin für Sozialforschung (WZB). https://doi.org/10.25522/manifesto.mpds.2020a

Walgrave, S., Joly, J., \& Sevenans, J. (2019). 'The Belgian Agendas Project' in Baumgartner, F. R., Breunig, C., \& Grossman, E. (Eds.). Comparative Policy Agendas: Theory, Tools, Data. Oxford: Oxford University Press, pp. 57-66.

*** Règlement de la Chambre des représentants (2019). Service Affaires juridiques et Documentation parlementaire de la Chambre des représentants D/2019/4686/06, available at:

https://www.lachambre.be/kvvcr/pdf sections/publications/reglement/reglement $\underline{\text { FR.pdf }}$ 


\section{Appendix}

Table A1: Matching of parliamentary committees and governmental portfolios by government

\begin{tabular}{|c|c|c|c|c|c|c|c|c|c|c|c|}
\hline Committee & Corresponding $\mathrm{mi}$ & sterial portfolio & & & & & & & & & \\
\hline & Martens IV & Martens V & Martens VI & Martens VIII & Dehaene I & Dehaene II & Verhofstadt I & Verhofstadt II & Leterme I & Di Rupo I & Michel I \\
\hline Defense & Défense nationale & Défense nationale & Défense nationale & & Défense & Défense & Défense & Défense & Défense & Défense & $\begin{array}{l}\text { Défense, } \\
\text { chargé de la } \\
\text { Fonction } \\
\text { publique }\end{array}$ \\
\hline Interior & Intérieur & $\begin{array}{l}\text { Intérieur et de la } \\
\text { Fonction publique }\end{array}$ & $\begin{array}{l}\text { Intérieur, de la } \\
\text { Fonction publique et } \\
\text { de la } \\
\text { Décentralisation }\end{array}$ & $\begin{array}{l}\text { Intérieur, de la } \\
\text { Modernisation } \\
\text { des services } \\
\text { publics }\end{array}$ & $\begin{array}{l}\text { Intérieur et de la } \\
\text { Fonction publique }\end{array}$ & Intérieur & Intérieur & Intérieur & Intérieur & $\begin{array}{l}\text { Intérieur et } \\
\text { de l'Égalité } \\
\text { des } \\
\text { chances }\end{array}$ & $\begin{array}{l}\text { Sécurité et de } \\
\text { l'Intérieur }\end{array}$ \\
\hline Infrastructure & $\begin{array}{l}\text { Travaux publics et des } \\
\text { Réformes } \\
\text { institutionnelles }\end{array}$ & Travaux publics & Travaux publics & Travaux publics & $\begin{array}{l}\text { Communications } \\
\text { et des Entreprises } \\
\text { publiques }\end{array}$ & Transports & $\begin{array}{l}\text { Télécommunicati } \\
\text { ons et des } \\
\text { Entreprises et } \\
\text { participations } \\
\text { publiques }\end{array}$ & $\begin{array}{l}\text { Budget et } \\
\text { des } \\
\text { Entreprises } \\
\text { publiques }\end{array}$ & $\begin{array}{l}\text { Fonction } \\
\text { publique et } \\
\text { des } \\
\text { Entreprises } \\
\text { publiques }\end{array}$ & $\begin{array}{l}\text { Entreprises } \\
\text { publiques, } \\
\text { de la } \\
\text { Politique } \\
\text { scientifique } \\
\text { et de la } \\
\text { Coopératio } \\
\mathrm{n} \text { au } \\
\text { développe } \\
\text { ment }\end{array}$ & Mobilité \\
\hline Justice & $\begin{array}{l}\text { Justice et des } \\
\text { Réformes } \\
\text { institutionnelles }\end{array}$ & $\begin{array}{l}\text { Justice et des } \\
\text { Réformes } \\
\text { institutionnelles }\end{array}$ & $\begin{array}{l}\text { Justice et des } \\
\text { Réformes } \\
\text { institutionnelles }\end{array}$ & $\begin{array}{l}\text { Justice et des } \\
\text { Classes moyennes }\end{array}$ & $\begin{array}{l}\text { Justice et des } \\
\text { Affaires } \\
\text { économiques }\end{array}$ & Justice & Justice & Justice & $\begin{array}{l}\text { Justice, } \\
\text { chargé des } \\
\text { Réformes } \\
\text { institutionn } \\
\text { elles }\end{array}$ & Justice & Justice \\
\hline Foreign affairs & Affaires étrangères & $\begin{array}{l}\text { Relations } \\
\text { extérieures }\end{array}$ & $\begin{array}{l}\text { Relations } \\
\text { extérieures }\end{array}$ & $\begin{array}{l}\text { Relations } \\
\text { extérieures }\end{array}$ & Affaires étrangères & Affaires étrangères & $\begin{array}{l}\text { Affaires } \\
\text { étrangères }\end{array}$ & $\begin{array}{l}\text { Affaires } \\
\text { étrangères }\end{array}$ & $\begin{array}{l}\text { Affaires } \\
\text { étrangères }\end{array}$ & $\begin{array}{l}\text { Affaires } \\
\text { étrangères, } \\
\text { du } \\
\text { Commerce } \\
\text { extérieur et } \\
\text { des Affaires } \\
\text { européenn } \\
\text { es } \\
\end{array}$ & $\begin{array}{l}\text { Affaires } \\
\text { étrangères et } \\
\text { européennes }\end{array}$ \\
\hline $\begin{array}{l}\text { Institutional } \\
\text { reform }\end{array}$ & $\begin{array}{l}\text { Justice et des } \\
\text { Réformes } \\
\text { institutionnelles }\end{array}$ & $\begin{array}{l}\text { Justice et des } \\
\text { Réformes } \\
\text { institutionnelles }\end{array}$ & $\begin{array}{l}\text { Justice et des } \\
\text { Réformes } \\
\text { institutionnelles }\end{array}$ & $\begin{array}{l}\text { Réformes } \\
\text { institutionnelles }\end{array}$ & & & & & $\begin{array}{l}\text { Justice, } \\
\text { chargé des } \\
\text { Réformes } \\
\text { institutionn } \\
\text { elles }\end{array}$ & $\begin{array}{l}\text { Secrétaire } \\
\text { d'État aux } \\
\text { Réformes } \\
\text { institutionn } \\
\text { elles }\end{array}$ & \\
\hline
\end{tabular}




\begin{tabular}{|c|c|c|c|c|c|c|c|c|c|c|c|}
\hline Finance & Finances & $\begin{array}{l}\text { Finances et du } \\
\text { Commerce } \\
\text { extérieur }\end{array}$ & Finances & Finances & Finances & $\begin{array}{l}\text { Finances et du } \\
\text { Commerce } \\
\text { extérieur }\end{array}$ & Finances & Finances & $\begin{array}{l}\text { Finances, } \\
\text { chargé des } \\
\text { Réformes } \\
\text { institutionn } \\
\text { elles }\end{array}$ & $\begin{array}{l}\text { Finances et } \\
\text { du } \\
\text { Développe } \\
\text { ment } \\
\text { durable (Ch } \\
\text { argé de la } \\
\text { Fonction } \\
\text { publique) } \\
\end{array}$ & Finances \\
\hline Social affairs & & & & Affaires sociales & $\begin{array}{l}\text { Affaires } \\
\text { sociales }\end{array}$ & Affaires sociales & $\begin{array}{l}\text { Affaires sociales } \\
\text { et des Pensions }\end{array}$ & $\begin{array}{l}\text { Affaires } \\
\text { sociales et de } \\
\text { la Santé }\end{array}$ & $\begin{array}{l}\text { Affaires } \\
\text { sociales et } \\
\text { de la Santé } \\
\text { publique }\end{array}$ & $\begin{array}{l}\text { Affaires } \\
\text { sociales et } \\
\text { de la Santé } \\
\text { publique }\end{array}$ & $\begin{array}{l}\text { Affaires } \\
\text { sociales et de } \\
\text { la Santé } \\
\text { publique }\end{array}$ \\
\hline $\begin{array}{l}\text { Economy \& } \\
\text { education }\end{array}$ & Éducation nationale & $\begin{array}{l}\text { Éducation } \\
\text { nationale }\end{array}$ & Éducation nationale & $\begin{array}{l}\text { Affaires } \\
\text { économiques, du } \\
\text { Plan et ministre } \\
\text { de l'Éducation } \\
\text { nationale }\end{array}$ & & $\begin{array}{l}\text { Économie et des } \\
\text { Télécommunicatio } \\
\text { ns }\end{array}$ & $\begin{array}{l}\text { Économie et de la } \\
\text { Recherche } \\
\text { scientifique }\end{array}$ & $\begin{array}{l}\text { Économie, de } \\
\text { l'Énergie, du } \\
\text { Commerce } \\
\text { extérieur et } \\
\text { de la } \\
\text { Politique } \\
\text { scientifique }\end{array}$ & $\begin{array}{l}\text { Économie, } \\
\text { de } \\
\text { l'Innovatio } \\
n \text { et de la } \\
\text { Simplificati } \\
\text { on } \\
\text { administrat } \\
\text { ive }\end{array}$ & $\begin{array}{l}\text { Économie, } \\
\text { des } \\
\text { Consomma } \\
\text { teurs et de } \\
\text { la Mer du } \\
\text { Nord }\end{array}$ & $\begin{array}{l}\text { Emploi, de } \\
\text { l'Économie et } \\
\text { des } \\
\text { Consommateu } \\
\text { rs (Chargé du } \\
\text { Commerce } \\
\text { extérieur) }\end{array}$ \\
\hline Trade & & & $\begin{array}{l}\text { Communications et } \\
\text { du Commerce } \\
\text { extérieur }\end{array}$ & $\begin{array}{l}\text { Commerce } \\
\text { extérieur }\end{array}$ & & & Justice & $\begin{array}{l}\text { Économie, de } \\
\text { l'Énergie, du } \\
\text { Commerce } \\
\text { extérieur et } \\
\text { de la } \\
\text { Politique } \\
\text { scientifique }\end{array}$ & $\begin{array}{l}\text { Justice, } \\
\text { chargé des } \\
\text { Réformes } \\
\text { institutionn } \\
\text { elles }\end{array}$ & Justice & Justice \\
\hline Business & Classes Moyennes & $\begin{array}{l}\text { Région bruxelloise } \\
\text { et des Classes } \\
\text { moyennes }\end{array}$ & Classes Moyennes & $\begin{array}{l}\text { Justice et des } \\
\text { Classes moyennes }\end{array}$ & $\begin{array}{l}\text { Agriculture et des } \\
\text { PME }\end{array}$ & & & & & & \\
\hline Labour & Emploi et du Travail & Emploi et du Travail & Emploi et du Travail & $\begin{array}{l}\text { Emploi et du } \\
\text { Travail }\end{array}$ & & & & & & & \\
\hline Agriculture & & $\begin{array}{l}\text { Secrétaire d'État } \\
\text { aux Affaires } \\
\text { européennes et à } \\
\text { l'Agriculture }\end{array}$ & $\begin{array}{l}\text { Secrétaire d'État aux } \\
\text { Affaires } \\
\text { européennes et à } \\
\text { I'Agriculture }\end{array}$ & & $\begin{array}{l}\text { Agriculture et des } \\
\text { PME }\end{array}$ & & & & & & \\
\hline
\end{tabular}


Table A2: Mapping of MARPOR categories for measuring party and cabinet policy positions and salience

\begin{tabular}{|c|c|c|}
\hline Policy area & $\begin{array}{l}\text { Position } \\
\text { MARPOR-categories used (per) }\end{array}$ & $\begin{array}{l}\text { Salience } \\
\text { MARPOR-categories used (per) }\end{array}$ \\
\hline Foreign affairs & $\begin{array}{l}\text { Plus pole: } \\
\text { 102: Foreign ( - ) } \\
\text { 109: Internationalism(-) } \\
\text { 110: EC(-) } \\
\text { Minus pole: } \\
\text { 101: Foreign (+) } \\
\text { 106: Peace } \\
\text { 107: Internationalism(+) } \\
\text { 108: EC(+) } \\
\text { 103: Anti-Imperialism }\end{array}$ & $\begin{array}{l}\text { 101: Foreign }(+) \\
\text { 102: Foreign }(-) \\
\text { 103: Anti-Imperialism } \\
\text { 106: Peace } \\
\text { 107: Internationalism(+) } \\
\text { 108: EC(+) } \\
\text { 109: Internationalism(-) } \\
\text { 110: EC(-) }\end{array}$ \\
\hline Defense & $\begin{array}{l}\text { Plus pole: } \\
\text { 104: Military }(+) \\
\text { Minus pole: } \\
\text { 105: Military }(-)\end{array}$ & $\begin{array}{l}\text { 104: Military (+) } \\
\text { 105: Military (-) }\end{array}$ \\
\hline Interior & $\begin{array}{l}\text { Plus pole: } \\
\text { 204: Constitutionalism (-) } \\
\text { 302: Centralisation } \\
\text { 305: Political Authority } \\
\text { 601: National Way of Life(+) } \\
\text { 603: Traditional Morality (+) } \\
\text { 605: Law and Order } \\
\text { 608: Multiculturalism (-) } \\
\text { Minus pole: } \\
\text { 201: Freedom and Human Rights } \\
\text { 202: Democracy } \\
\text { 203: Constitutionalism (+) } \\
\text { 301: Decentralisation } \\
\text { 602: National Way of Life (-) } \\
\text { 604: Traditional Morality (-) } \\
\text { 607: Multiculturalism (+) }\end{array}$ & $\begin{array}{l}\text { 201: Freedom and Human Rights } \\
\text { 202: Democracy } \\
\text { 203: Constitutionalism (+) } \\
\text { 204: Constitutionalism (-) } \\
\text { 301: Decentralisation } \\
\text { 302: Centralisation } \\
\text { 303: Governmental and } \\
\text { Administrative Efficiency } \\
\text { 304: Political Corruption } \\
\text { 605: Law and Order } \\
\text { 607: Multiculturalism (+) } \\
\text { 608: Multiculturalism (-) }\end{array}$ \\
\hline Economy & $\begin{array}{l}\text { Plus pole: } \\
\text { 401: Free Enterprise } \\
\text { 402: Incentives } \\
\text { 407: Protectionism (-) } \\
\text { 414: Economic Orthodoxy } \\
\text { Minus pole: } \\
\text { 403: Market Regulation } \\
\text { 404: Economic Planning } \\
\text { 406: Protectionism(+) } \\
\text { 409: Keynesian Demand Management } \\
\text { 412: Controlled Economy } \\
\text { 413: Nationalisation } \\
\text { 415: Marxist Analysis }\end{array}$ & $\begin{array}{l}\text { 401: Free Enterprise } \\
\text { 403: Market Regulation } \\
\text { 404: Economic Planning } \\
\text { 405: Corporatism } \\
\text { 406: Protectionism(+) } \\
\text { 407: Protectionism (-) } \\
\text { 408: Economic Goals } \\
\text { 409: Keynesian Demand Management } \\
\text { 410: Productivity } \\
\text { 412: Controlled Economy } \\
\text { 413: Nationalisation } \\
\text { 415: Marxist Analysis }\end{array}$ \\
\hline
\end{tabular}




\begin{tabular}{|c|c|c|}
\hline Finance & $\begin{array}{l}\text { 402: Incentives } \\
\text { 414: Economic Orthodoxy }\end{array}$ & $\begin{array}{l}\text { 402: Incentives } \\
\text { 414: Economic Orthodoxy }\end{array}$ \\
\hline Health & $\begin{array}{l}\text { Plus pole: } \\
\text { 505: Welfare State Limitation } \\
\text { Minus pole: } \\
\text { 504: Welfare State Expansion } \\
\text { 706: Non-economic Demographic } \\
\text { Groups }\end{array}$ & $\begin{array}{l}\text { 504: Welfare State Expansion } \\
\text { 505: Welfare State Limitation } \\
\text { 706: Non-economic Demographic } \\
\text { Groups }\end{array}$ \\
\hline Justice & $\begin{array}{l}\text { Plus pole: } \\
\text { 204: Constitutionalism (-) } \\
\text { 303: Governmental and Administrative } \\
\text { Efficiency } \\
\text { 304: Political Corruption } \\
\text { 605: Law and Order } \\
\text { Minus pole: } \\
\text { 201: Freedom and Human Rights } \\
\text { 202: Democracy } \\
\text { 203: Constitutionalism }(+)\end{array}$ & $\begin{array}{l}\text { 201: Freedom and Human Rights } \\
\text { 202: Democracy } \\
\text { 203: Constitutionalism (+) } \\
\text { 204: Constitutionalism (-) } \\
\text { 303: Governmental and } \\
\text { Administrative Efficiency } \\
\text { 304: Political Corruption } \\
\text { 605: Law and Order }\end{array}$ \\
\hline Labour & $\begin{array}{l}\text { Plus pole: } \\
\text { 505: Welfare State Limitation } \\
\text { 702: Labor Groups(-) } \\
\text { Minus pole: } \\
\text { 504: Welfare State Expansion } \\
\text { 701: Labor Groups(+) }\end{array}$ & $\begin{array}{l}\text { 504: Welfare State Expansion } \\
\text { 505: Welfare State Limitation } \\
\text { 701: Labor Groups(+) } \\
\text { 702: Labor Groups(-) }\end{array}$ \\
\hline Education & $\begin{array}{l}\text { Plus pole: } \\
\text { 507: Education Limitation } \\
\text { Minus pole: } \\
\text { 506: Education Expansion }\end{array}$ & $\begin{array}{l}\text { 506: Education Expansion } \\
\text { 507: Education Limitation }\end{array}$ \\
\hline Environment & $\begin{array}{l}\text { Plus pole: } \\
\text { 410: Productivity } \\
\text { Minus pole: } \\
\text { 416: Anti-Growth Economy } \\
\text { 501: Environmental Protection }\end{array}$ & $\begin{array}{l}\text { 416: Anti-Growth Economy } \\
\text { 501: Environmental Protection }\end{array}$ \\
\hline Social affairs & $\begin{array}{l}\text { Plus pole: } \\
\text { 603: Traditional Morality }(+) \\
\text { 606: Social Harmony } \\
\text { 704: Middle Class, Professional } \\
\text { Minus pole: } \\
\text { 503: Social Justice } \\
\text { 604: Traditional Morality (-) } \\
\text { 705: Underprivileged Minority } \\
\text { 706: Non-economic Demographic } \\
\text { Groups }\end{array}$ & $\begin{array}{l}\text { 503: Social Justice } \\
\text { 603: Traditional Morality (+) } \\
\text { 604: Traditional Morality (-) } \\
\text { 606: Social Harmony } \\
\text { 704: Middle Class, Professional } \\
\text { 705: Underprivileged Minority } \\
\text { 706: Non-economic Demographic } \\
\text { Groups }\end{array}$ \\
\hline Trade & $\begin{array}{l}\text { Plus pole: } \\
\text { 407: Protectionism (-) } \\
\text { Minus pole: } \\
\text { 406: Protectionism (+) }\end{array}$ & $\begin{array}{l}\text { 406: Protectionism(+) } \\
\text { 407: Protectionism (-) }\end{array}$ \\
\hline
\end{tabular}




\begin{tabular}{|l|l|l|}
\hline Agriculture & 703: Agriculture and Farmers $(+)$ & 703: Agriculture and Farmers (+) \\
\hline Infrastructure & 411: Technology and Infrastructure $(+)$ & 411: Technology and Infrastructure $(+)$ \\
\hline Business & 402: Incentives & 402: Incentives \\
& 704: Middle Class, Professional & 704: Middle Class, Professional \\
\hline
\end{tabular}

Note: adapted from Bäck et al (2011) and Hohendorf et al (2020).

Bäck, H., Debus, M. and Dumont, P., 2011. Who gets what in coalition governments? Predictors of portfolio allocation in parliamentary democracies. European Journal of Political Research, 50(4), pp.441-478.

Hohendorf, L., Saalfeld, T. and Sieberer, U., 2020. Veto power fosters cooperative behaviour: institutional incentives and government-opposition voting in the German Bundestag. West European Politics, pp.1-25. 
Table A3: Determinants of chair allocation (multinomial logistic regression)

\begin{tabular}{lll}
\hline & $\begin{array}{l}\text { Shadow } \\
\text { chair }\end{array}$ & $\begin{array}{l}\text { Same party } \\
\text { chair }\end{array}$ \\
\hline & M1 & M1 \\
\hline Ideological distance - party level & $2.39^{*}$ & 1.02 \\
& $(1.11)$ & $(0.51)$ \\
Ideological distance - portfolio level & 1.00 & 0.93 \\
& $(0.27)$ & $(0.23)$ \\
Portfolio saliency & 0.98 & 0.98 \\
& $(0.03)$ & $(0.03)$ \\
Watchdog junior minister & 4.71 & 2.47 \\
& $(5.97)$ & $(3.39)$ \\
Coalition agreement length & 1.00 & 1.00 \\
& $(0.00)$ & $(0.00)$ \\
Minimum winning coalition & $2.69^{* *}$ & 2.04 \\
& $(1.25)$ & $(1.30)$ \\
Minister party's seat \% & 0.97 & 0.92 \\
& $(0.03)$ & $(0.05)$ \\
Number seats held by chair's party & 1.00 & $0.92^{* * *}$ \\
& $(0.02)$ & $(0.02)$ \\
\hline N & & 120 \\
McFadden's ${ }^{2}$ & & 0.099 \\
\hline
\end{tabular}

Notes: Significance at ${ }^{*} \mathrm{p}<0.10,{ }^{* *} \mathrm{p}<0.05,{ }^{* * *} \mathrm{p}<0.01$. Opposition chair is the baseline.

Cell entries are relative risk ratios. Robust standard errors clustered by cabinet in parentheses. 
Table A4: Controlling for government formation duration

\begin{tabular}{lll}
\hline & M1 & M2 \\
\hline Ideological distance - party level & $2.42^{* * *}$ & $2.07^{*}$ \\
& $(0.82)$ & $(0.78)$ \\
Ideological distance - portfolio level & 1.05 & 1.04 \\
& $(0.25)$ & $(0.31)$ \\
Portfolio saliency & 0.99 & 0.98 \\
& $(0.02)$ & $(0.03)$ \\
Watchdog junior minister & $2.46^{*}$ & 4.85 \\
& $(1.24)$ & $(5.86)$ \\
Coalition agreement length & 1.00 & 1.00 \\
& $(0.00)$ & $(0.00)$ \\
Minimum winning coalition & $1.92^{* * *}$ & $2.38^{* *}$ \\
& $(0.41)$ & $(0.98)$ \\
Minister party's seat \% & 1.01 & 0.97 \\
& $(0.04)$ & $(0.03)$ \\
Number seats held by chair's party & $1.04^{* * *}$ & 1.00 \\
& $(0.02)$ & $(0.02)$ \\
\hline $\mathrm{N}$ & 120 & 79 \\
McFadden's $\mathrm{R}^{2}$ & 0.078 & 0.084 \\
\hline
\end{tabular}

Notes: Significance at ${ }^{*} \mathrm{p}<0.10,{ }^{* *} \mathrm{p}<0.05,{ }^{* * *} \mathrm{p}<0.01$

Cell entries are odds ratios. Robust standard errors clustered by cabinet in parentheses. 
Table A5: Alternative portfolio saliency measures

\begin{tabular}{llll}
\hline & M1 & M2 & M3 \\
\hline Ideological distance - party level & $2.23^{*}$ & $2.36^{* * *}$ & $2.10^{* *}$ \\
& $(0.92)$ & $(0.77)$ & $(0.74)$ \\
Ideological distance - portfolio level & 1.07 & 0.99 & 0.93 \\
& $(0.30)$ & $(0.18)$ & $(0.24)$ \\
Portfolio saliency for party of committee chair & 0.97 & & \\
& $(0.02)$ & & \\
Portfolio saliency (Druckman \& Warwick 2005) & & 1.15 & 0.35 \\
& & $(0.91)$ & $(0.42)$ \\
Watchdog junior minister & 5.28 & $2.59^{* *}$ & 6.06 \\
& $(6.76)$ & $(1.13)$ & $(6.67)$ \\
Coalition agreement length & 1.00 & 1.00 & 1.00 \\
& $(0.00)$ & $(0.00)$ & $(0.00)$ \\
Minimum winning coalition & $2.76^{* *}$ & $1.93^{* * *}$ & $2.52^{* *}$ \\
& $(1.16)$ & $(0.41)$ & $(1.08)$ \\
Minister party's seat \% & 0.97 & 1.01 & 0.97 \\
& $(0.02)$ & $(0.04)$ & $(0.03)$ \\
Number seats held by chair's party & 1.00 & $1.04^{* * *}$ & 1.00 \\
& $(0.02)$ & $(0.02)$ & $(0.02)$ \\
\hline N & 79 & 120 & 79 \\
McFadden's R ${ }^{2}$ & 0.094 & 0.077 & 0.085 \\
\hline
\end{tabular}

Notes: Significance at ${ }^{*} \mathrm{p}<0.10,{ }^{* *} \mathrm{p}<0.05,{ }^{* * *} \mathrm{p}<0.01$

Cell entries are odds ratios. Robust standard errors clustered by cabinet in parentheses. 